\title{
Khaldunian Understanding of Economico-Legal Philosophy: A Living Mechanism for Civilizational Existence*
}

\author{
Ibn Haldun'un Iktisadi Hukuk Felsefesi Anlayışı: Medeni \\ Yaşam için Canlı bir Mekanizma
}

\author{
(iD) Mohammad Zakaria \\ International Islamic University Malaysia (IIUM) \\ gazilawdu36@gmail.com
}

Received: June 5, 2019

Accepted: November 13, 2019

Published: January 15, 2020

\begin{abstract}
Ibn Khaldun is one of the erudite Islamic polymaths. Though he had contributed, as the biographic corpus suggests, to wide range of sociology, jurisprudence, historiography and economico-political philosophy, Ibn Khaldun is best known for his historiographical contribution. Hence his dynamic economic understanding, though pre-modern yet well capable of answering even the postmodern economic questions, almost remains terra incognita to many people. This paper, in adopting doctrinal method and comparative jurisprudential approach, has attempted to explore Khaldunian economic views with special focus on examining the core characteristics of three ideas of kasb ma'āsh and jibāyah (later referred to as KAMAJ) as to how these three tools, if developed and cultivated in a mutually exclusive framework, make a given nation blossom and flourish, and absence of which, especially rigging jibāyah (taxation) policy, may corrode production industries, consequentially leading a given country to the cataclysmic escalation of decadence and disappearance from civilizational cartography. By so presenting, the study has demonstrated that Khaldunian economic conceptions would be a better alternative-not pioneer in the theorization of economics as seen by some academics-to the western economic thought.
\end{abstract}

Keywords: Ibn Khaldun, Kasb, Taxation, Wealth Generation, Sustainable Economic Theory

Özet: Ibn Haldun mütebahhir Islam bilginlerinden biridir. Her ne kadar hakkındaki biyografik kaynakların ileri sürdügü üzere sosyoloji, hukuk, tarih yazımı ve politik ekonomi gibi çok geniş alanlardaki çalışmalara iştirak etmiş olsa da kendisi daha çok tarih yazımı ile ilgili katkılarıyla tanınmaktadır. Dolayısıyla onun, modern öncesi olmasına karşın post modern ekonomik

ORC-ID: M. Zakaria 0000-0003-1982-5398

"This article is a review of the paper presented at the "5th International Ibn Khaldun Symposium" organized on 27-28 April 2019 in Istanbul. 
problemlere dahi yeteri kadar cevap verebilecek ehliyete sahip olan dinamik ekonomik anlayışı neredeyse birçokları için bir terra incognita olarak kalmış vaziyettedir. Bu makale, doktrinel metot ve karşılaştırmalı hukuki yaklaşımı benimseyerek, hususi olarak kesb, maaş ve (daha sonra KAMA) olarak bahsedilecek) cibayet (vergi) düşüncelerinin esas niteliklerini ele alıp Ibn Haldun'un iktisadi görüşlerini keşfetmeye çalışmakta ve karşılıklı olarak münhasır bir çerçeve içerisinde gelişstirilip işlendiği takdirde bu üç aracın belirli bir milleti nasıl canlandırıp ilerleteceğini ve yokluğunun da, özellikle cibayet politikasının düzmece şekilde tesis edildiği bir durumda, üretim endüstrisinin nasıl aşınabileceğini ve buna mukabil nasıl bir milleti medeniyet atlasında kaybolmaya ve çöküşün yıkıcı eşiğine sürükleyebileceğini incelemektedir. Böylesi bir sunumla bu çalışma, Ibn Haldun'un iktisadi kavramlarının -bazı akademisyenlerin gördüğü üzere ekonomi biliminin teorileşmesinin bir öncüsü değil- batı iktisadi düşüncesine yönelik daha iyi bir alternatif olabileceğini ortaya koymaktadır.

Anahtar Kelimeler: Ibn Haldun, Kesb, Vergilendirme, Refah Nesli, Sürdürülebilir Ekonomik Teori

\section{Introduction}

Islamically viewing, philosophical act is an engagement with the reality through the lens of observation and experience. ${ }^{1}$ Hence economico-legal philosophy implies to a thought which would and should be based on experienced economico-judicial activism and observation, and not founded on numbers and symbols alone. Inspired by tremendous inclusivity of Islamic intellectual heritage ${ }^{2}$ and having empirically experienced a multitude of executive and judicial offices ranging from deputy ministry to the office of chief justice, Ibn Khaldun might have instilled such dynamic functionaries into his

\footnotetext{
1 Unlike the existing western enervating philosophy, Islamic philosophical understanding always stands on the premise of the tradition of utilizing the concept of nazar (philosophization) which bound the Muslim scholars, engaging in the philosophization of any fact, to constantly refer to the metaphysical source of the Ultimate Authority of knowledge, wisdom and everything that enabled them to walk the right path. Such motivation would be understood from the Quranic verses. See Al-Quran, 59:18, 7:84, 27:14, 10:73.

2 The holy Quran ascribes pre-eminence to wealth management. It clearly orders that "do not give your properties to the stupid which Allah has made the mechanisms for survival..." (Al-Quran, 4:5) The Book of Allah Subhānahu mentions regarding $m \bar{a}$ /(property) roughly more than 86 places. As the Quran unequivocally describes wealth as the tool for survival and Prophetic teachings offer practical example, the Rashidun period including all the later Muslim Establishments have payed huge importance to the wealth management. Kitāb al-Kharāj by 'Abū Yūsuf (d. 182 H), Kitāb Aḥkam al-Awqāf by Hilāl b. Yaḥyāal-Bașrī (d. 245 H), Kitāb al-Amwāl by Ḥumaid b. Zanjawiyyah (d. 251 H), Kitāb al-Amwāl by 'Abū 'Ubaid Qāsim b. Sallām (d. 224 H), Kitāb alKharāj by Yaḥyā b. Ādam al-Qarshī (d.203 H), Kitāb Aḥkam al-Awqaf by Imam al-Khaș̣af al-Shaibāni (d.261 H), Kitāb al-Amwālby Abu Jafar al-Dawudi (d. 402 H), Kitāb al-Istikhrāj li Aḥkām al-Kharāj by lbn Rajab Ḥanbalī (d. $790 \mathrm{H}$ ) and al-ls'āf fì Ahkām al-Awqāf by Ibn Abi Bakr al- Ṭarablusī (d.922 H), Tasjīl al- Awqāf, Risālah fì Masāil al-wuqūf, Bị̂ā'a al-Qāọi fĩ al-Ṣukūk and Qānūn al-Mu'amalāt by 'Abū al-Sa'ud Āfindī (d. 982 H)would be grim illustration of how Islam taught its followers regarding the importance of wealth. It is also to be noted that all the Fiqh manuals contain chapters dealing with how to engage economic activities. Obviously Ibn Khaldun was one of the erudite sequels to this dynamic and brilliant intellectual heritage.
} 
politico-intellectual versatile workmanship. A deep inquiry into his scholarly legacy related to economic affairs suggests that he had woven his economic ideas with an intertwining living thread of iqtișa $\bar{d} d^{3}$ and jurisprudence. The study has argued that once the various layers of the tapestry of his economic scholarship got successfully unfolded, economic leaders would benefit from the lessons emergent from the thread.

Viewed in the above way the paper has tried to explore that Khaldunian economic views of kasb ma'āsh and jibāyah (later referred to as KAMAJ) are not only three core components of economic activities per se. Rather it better represents the theory of having a large number of economic activities as, Antonio Seer proposes, ${ }^{4}$ which may allow a given nation blossom, flourish and ultimately emulate its counterparts, and absence of which, especially rigging jibāyah (taxation) policy 5 , may corrode wealth generating forces and their entrepreneurships and, ultimately contributing to the recession of those entrepreneurships, such inertia would lead a country to the cataclysmic escalation of decadence and disappearance from civilizational cartography. A huge data would back up the above claim. British Bengal would be a grim illustration of how the richest part of the globe turned to be one of the poorest countries of the time. ${ }^{6}$ In this regard the study has argued that long before 'an Inquiry into the Nature and Causes of the Wealth of Nations' by Adam Smith, Ibn Khaldun had categorized pivotal spectra of wealth generation and also offered the theoretical premise of incubating those wealth industries in a much more sophisticated way.

\footnotetext{
${ }^{3}$ We have preferred iqtișād to economics, because, the former implies to a set of transaction principles which better nurtures faläh hegemony mandating both individuals and society to strive towards a true success in this world and the next. The latter, In contrast, refers to capital hegemony which deals with the conviction of accumulating money and wealth no matter event at the cost of others including environmental degradation and at the expense of the hereafter life.

${ }^{4}$ A seventeenth century Neapolitan jurist who is the first western economist to produce the theory of uneven economic development Breve trattato or 'Brief treatise' in 1613. It is worth noticing here that long before him has the Quranic verses provisioning about ribā (interest/usury) clearly articulated the very concept of uneven economic development. See Al-Quran, 30:39, 2:275, 13:17.

${ }^{5}$ We have understood jibāyah not only to be the taxation law and policy per se, rather to be whole set of laws and regulations including export and import laws and the laws of international organizations that for practical reasons influence the domestic economic activities of a given country. Thus, in the context of present global economic endeavors, a country must know when why and how to sign any regulation/s of international organizations which may negatively affect the domestic production industry.

${ }^{6}$ Hunter tellingly comments "A hundred and seventy years ago it was almost impossible for a well-born Musalman in Bengal to become poor; at present it is almost impossible to him to continue rich." To know in further details, see W.W. Hunter, The Annals of Rural Bengal, vol. I, (London : Smith Elder Co, 1868)
} 
In the process of his structuring jibāyah principles, Ibn Khaldun thinks that the legislator must promulgate wealth industries-friendly taxation policies which embolden the industries' producing capacity. He strongly suggests that it would not be appropriate to tax the citizenry in general and production industry in particular in a way which, intervening the due course of wealth generation enterprise, may alarmingly decrease the volume of wealth production domain and ultimately push the given nation deep into deficits. We find his discussion on kasb-ma'āsh drive together with jibāyah policy as having viewed that economic institutions should run in a mutually exclusive manner yet in line with state machineries (Ibn Khaldun, 2001, p: 477).

The paper has contended that Ibn Khaldun's economico-legal understanding is an advocate of intrinsically monetary value-based economic system which for sure would foster a sustainable economic platform inspired by both the local and international interests as opposed to the capitalist economic system, which, allowing unqualified absolutism, has been almost plaguing post-modern economic life. The study has further maintained that Khaldunian synthesization of wealth management would better serve in understanding and realizing the sustainability drives, and may nurture morality, sustainability and justice and reconcile the dichotomy between economic development and social justice and moral values in both national and global economic engagements. And as such, Khaldunian economic tradition function as a better alternative-not pioneer in the theorization of economics as seen by some academics-to the western economic thought.

With the above concerns in mind, the second section translates Khaldunian KAMAJ episteme into contemporary economic spectra to see how it may provide a given country driving mechanisms for survival, and whether it may cover wider swath of domestic production industry that would compete the global economic market. And then a comprehensive explanation is dedicated to the concept of jibāyah. The concept will discover itself in an extended structure both in domestic law and global governance. The third section investigates the reasons of the planet being so despicably unsustainable. The fourth section tries to locate Khaldunian integrated economico-legal pattern in the context of the Millennium Development Goals (the MDGs) to what extent it would function as an alternative mechanism to the existing defunct economic policies in redressing the sustainability drives. Herein a set of recommendations is offered to how best reconcile the dichotomy between domestic economic growth and international trade drives, and guarantee climate friendly economic engagement. And the final section ends with a concluding remark. 


\section{Exploring and Theorizing Khaldunian Economic Views}

Before the essay follows the illustration, it would be worth reading few more words which may allow the import of the paper to be unfolded in a cohesive navigation. A long-lasting harmonious economics would be the one whose foundation is based on not top down but bottom up structure yet in line with both the drives of moral philosophy and the best interests of the environment. Because production which stands at the core of human economic activities (Reinert, 2007, p: 69) also springs from individual/s' labors and efforts. And combination of individuals (landowner, financier and worker) leads to the formation of entrepreneurship. Sizable wages and increasing returns embolden the economic entrepreneurship (platform for rendering production-labor) and revigorate the maximum labor productivity. All these happen only when domestic laws create a proactive legal and regulatory body responsible for the economic affairs of the state strong enough in protecting the interests of trade industry, small and big, against both the heavy burden of taxation and attacks of orthodoxy trading engagement of international economic communities. To put it otherwise, an inclusive legislation which puts the interests of sustainable economic affairs of the state at the forefront of its founding policies would permit the given country to survive both the national and international economic challenges, and hence, trigger itself to emulate its international counterparts in the long race of global trade. With that background in mind, now the treatment of Khaldunian KAMAJ theory will be briefly analyzed.

\subsection{Khaldunian Kasb-Ma'āsh Episteme}

In order to articulate the ways of how to survive the challenges of existence, Ibn Khaldun imports three different words in the discussion, for example, kasb (earning), rizq (provision) and ma'āsh (livelihood). He says: human being needs tools [of survival] which he lives on, grows and ages all the way from the inception of his birth to the old age. He then cites the verse: And Allah is of course rich alone and you all are destitute. He mentions that Allah created everything in the universe for the benefit of human beings. He argues that for this reason human beings have equal share in generating profit by utilizing the natural resources. One who becomes able to earn livelihood, ibn Khaldun thinks, does not take the property of others except for consideration

Ibn Khaldun contends that once human being overcomes the stage of weakness and gets capable of generating wealth, he engages in acquiring provisions so that he may spend his wealth [according to the recognized transaction laws] in meeting his needs and necessities. Though he is seen to have distinguished between and among kasb and rizq and mash, riāsh and mutamawwil (Ibn Khaldun, 2001, p: 477), he finally heads to 
channel the concepts of mash and kasb to be pivotal premise of wealth generation and management. He explains how to attain kasb. He says: it should be understood that kasb is actuated through strong determination for the acquisition of wealth and practically employing entrepreneurship for that cause. Hence it is compulsory to strive towards acquiring wealth. It is even still necessary in your way to find out the earning tools (Ibn Khaldun, 2001, p: 478).

Employment should always, thinks ibn Khaldun, be there in regenerating more wealth from already earned provision and capital. He then turns to two precious stones-gold and silver. To him, these two stones are the inherently valued stones and hence deserve to be the media of trading exchanges. All other economic activities are in essence seen to be directing to these precious substances. Here we would add that, one of the fundamental reasons for inconceivable economic imbalance and unsustainability has been formally caused by the initiation of FIAT money ${ }^{7}$ characterized by the fashion and inclination of Bretton Woods Conference. Khaldunian treatment of gold and silver as the ever-living media of exchange may restructure the existing global (economic) leaders' policy concerns.

Ibn Khaldun pressingly emphasizes the role of strong determination and ambition of the people in generating wealth. For him, hope for better living and dignified survival give the people impetus to the wealth generation struggles, and as will be seen later in the section of jibãyah, loss of hope for sure pushes them back from that engagement which may eventually cause the national deficits (Ibn Khaldun, 2001, pp: 476-79).

In his discussion on ma'āsh, Ibn Khaldun explores multitudes of tools and mechanisms which naturally facilitate human being to make livings and generate wealth. He says: "ma'āsh implies to an attempt to quest provision and [in order to acquire that provision] employ human endeavor accordingly. Ma'āsh, he continues, has been named as ma'āsh, because, it is derived from 'aish meaning to survive, or live a life. And ma'āsh etymologically means the time and or place of survival. As though he seems to argue that for one's survival as an individual and as a nation, he must know and map his own time and place's mechanisms of how to generate wealth and manage in a functioning manner.

\footnotetext{
7 Imran N. Hosein, The Gold Dinar and Silver Dirham: Islam and the Future of Money, (San Fernando: Masjid Jāmia Publication, 2007), has offered a good account of the predicament of paper money.
} 
With that definition in mind, Ibn Khaldun categorizes various ways of ma'āsh. He thinks that mash would be made by employing other human beings' labor according to the recognized law which is branded as magrama $^{8}$ and jibāyah. ${ }^{9}$ [as will be observed in the next discussion, it is incomes of the state.] Mash would be also entertained by hunting wild animals. It may be attained by selling benefits from the tamed animals (Ibn Khaldun, 2001, p: 479). Kasb may also be done by employing human services in certain components like script writing, trading, sewing, knitting, horsemanship and the like, or in undefined sections which involve all types of labors and efforts. It may be gained through producing and manufacturing goods [in national and international market]. [by employing labor once you generate produces and goods], you may sell it in local market, or for greater benefit either merchandize from cities to cities (it may represent today's international trade) or hoard intact with the hope of better price in the future. To him it is called business/trade (Ibn Khaldun, 2001, p: 480).

For ibn Khaldun, ma'āsh is an inclusive mechanism that may cover anything which would facilitate the people to generate wealth ranging from agricultural activities to the craftings. In order to substentite the meaning given to ma'āsh, Ibn Khaldun cites Harīīi 10, and summarizes the concept in the following way: ma'āsh is 'imārah (earning custom duties through governance), filāha (farming), tijāra (trading) and șinā'a (crafting). 'Imārah is concerned with the state machineries. Filăha is the founding, not the only source, as the physiocrats thought back in the $18^{\text {th }}$ century France (Reinert, 2007, P.xxii), of ma'āsh, and the rest spring from it if cultivated and nurtured accordingly.

\subsubsection{Theorization of Khaldunian Economic Tradition}

The above exploration may yield a set of propositions which would be summarized in the following theoretical framework.

Kasb-ma'äsh drive is a self-consciously mandatory move of employment which may enable every individual to strive towards generating incomes. And the same stimulus encourages them to produce more goods or render more services, physical and or intellectual, which eventually bring handsome figure of earnings/profits, and hence provide them better tools for survival. Therefore, it may be argued that economic growth is central to the Khaldunian economic tradition. However, unlike one-eyed modern

\footnotetext{
8 Incomes in the form of fines and compounds emergent from criminal infringements of individuals.

9 Here it refers to the incomes of the state received in the forms of custom duties, revenues, pecuniary fines for criminal infringements and so forth.

10 Abū Muḥammad al-Qāsim b. Alī b. Muhammad b. Uthmān al- Ḥarīrī al-Bașri al-Ḥarramī (446 H/ 1054$516 / 1112$ ) is one of the legendary figures in Arabic literature.
} 
economics, Khaldunian economic tradition proposes an integrated model which necessitates multi-folded just premise of economic engagement ${ }^{11}$ and negates any concern/s which are likely to nurture certain individuals' economic interests to the neglect of others.

Khaldunian Kasb-ma'āsh drive may offer multitudes of production mechanisms which would allow the people to restructure their generation technics in line with the changing phases of economic activities. In other words, Khaldunian kasb-ma'āsh drive is an ontological mechanism which would show the clearest pathway to the most updated economic activities ever possible. Arguably, in the existing globalized setting, khaldunian economic model may guarantee the inclusive economic paradigm which would help survive the digitized challenges.

As the inclusive work forces of a nation ranging from farmer to professor in the context of khaldunian economic tradition are the heart of national economy, kasb-ma'āsh drive together with the jibāyah policy, (a concept explained in the next discussion) mandates the state to introduce a strong legal mechanism which through their economic-legal policies not only protect the interests of economic affairs of the production industry but also survive and emulate international counterparts, adopt policies and laws in line with the changing phases of domestic and international economic markets.

The art of manufacturing has a tremendous effect to impact on the speedy economic affairs. To quote Ferdinando Galiano, an eighteenth century prominent Italian economist (Reinert, 2007), 'from manufacturing you may expect the two greatest ills of humanity, superstition and slavery, to be healed'. A timely manufacturing mechanism thus is the only gateway into the globalized economic world. It is worth mentioning that Khaldunian economic tradition successfully addresses the art of manufacturing. The idea of Ma'assh together with the understanding of i'dād al-bad $\bar{a} i^{\uparrow}{ }^{\imath}$ may lead to the introduction of an effective manufacturing sector that would solve the core economic problems of any given nation.

\footnotetext{
11 Four different types of justice-commutative, contributive, distributive and legal justice- are seen to be gaining popularity in both academia and public squire. 'Adl-zulm (justice-injustice) binary as understood from the Khaldunian economico-legal discourse, is an enormously rich venue which inherently involves all these dimensions of justice and even beyond.

12 It means to prepare goods. Ma'āsh literally refers to the time and space in which effort of generating livelihood takes place. Hence ontologically speaking, the concept of Ma'āsh together with the idea of i'dād albaḍa $i^{\prime}$ 'would be better understood to be the manufacturing section in today's economic context.
} 


\subsection{Khaldunian Jibāyah Institution}

An in-depth reading of Ibn Khaldun's jibāyah episteme reveals that he does not talk only about collecting custom duties per se; rather he inclines to advice how a nation may economically flourish. Thus we are convinced to liken the khaldunian jibāyah discourse to the institution of wealth management. We briefly explore his thought on jibãyah coupled with some other key concepts mentioned side by side with jibāyah. For Ibn Khaldun, any likely successful government imposes low duties which in return brings huge incomes to the state treasury. On the contrary, a declining state, he contrasts, applies heavy duties which results in less incomes (Ibn Khaldun, 2001, p: 344). Ibn Khaldun says: if government administers its whole organs on the basis of din (religion), it only demands the Shari'ah imposed taxes, i. e., șadaqāt, kharāj and jiziyah[-three vehicles of claiming custom duties from the subjects of Islamic government].

We argue that all three words cover a wider set of taxation institutions as understood within the purview of al-siyãsa al-shar'iyyah. He rightly observes that [based on the understanding of mas /aha-public welfare] Shari'ah incumbrancers [pertaining to custom duties or revenues] count a lot not to be easily calculated (Ibn Khaldun, 2001, p: 344).

When so (due to less custom duties, passion gets stronger) happens, citizens get inspired to work more (Ibn Khaldun, 2001, p: 344). Their productivity tremendously increases which eventually triggers the flourishing of the country [globally]. He then turns to view that, when the government of growing nation indulges the luxurty, it turns the government officials seriously consumeristic, consequently leading them to impose heavy taxes on the subjects in order to further their consumption. Ultimately extra burden of taxes and duties dishearten the people from having further financial activities. It also facilitates the administrators to corrupt themselves under the aegis of collecting more custom duties. Hence result has to become a shambles. When you understand the policy explained above, advises Ibn Khaldun, you must know that a possibly reasonable minimum duties upon the production industry would be one of the founding reasons for civilizational advancement, as it emboldens the hearts of production industry ${ }^{13}$ (Ibn Khaldun, 2001, p: 345).

One of the key reasons for the decadence of a government, he mentions, is the engagement of the government in business activities. For him, ruler/s' involvement in business leads to dishearten the hope and expectation of production industry which

\footnotetext{
13 The term should not invite misconceptions. According to Khaldunian economic views, production industry involves every single individual's work efficiency who may somehow contribute to the national economy.
} 
would ultimately leave them hopeless, and hence non-operative (Ibn Khaldun, 2001, p: 347). He reasons that market is the place where products of agricultural activities, business entrepreneurships and craftings are displayed with the hope of making profits through exchanges. When ruler himself brings the goods in market, it poses a sheer monopoly giant for ruling machines. Eventually competitive character of market may disappear which is the important impetus to generate profit through trading goods in market (Ibn Khaldun, 2001, p: 347). Consequently rulers' involvement in business may force the production industry to stagnate pushing the national economy into deficits (Ibn Khaldun, 2001, p: 347).

Policy of how to maximize government incomes through the realization of various custom duties and tolls is central to the Khaldunian economic tradition. One may find Ibn Khaldun repeatedly advises state machineries concerning the state's economic growth. He says: "it should be understood that ruler cannot make economic growth and cannot flourish except without incomes [realized through the well administered institutions of tax management system]. And it would be possible through ensuring justice to the production industry (land owner, financier, workers and all other groups somehow concerned with wealth generation) and maintaining strong concern for their advancement. In this way, their ambitions will grow, their hearts will get filled with ventures and energies in producing goods and increasing them [to the maximum level]. Eventually incomes will tremendously increase (Ibn Khaldun, 2001, pp: 348-9). If incomes collected from the citizens, he argues, is not discharged accordingly; rather decreased in grants and donation, it will ultimately affect the body of jibāyah (incomes) (Ibn Khaldun, 2001, p: 353). Hence in his jibāyah discourse, the concept of zulm (injustice) occupies a very significant place. More than five pages have been dedicated on the discussion of żulm (injustice).

Ibn Khaldun views: "oppression takes away all the hopes and aspirations from the people. The production will diminish to the extent of oppression. If injustice rules, the whole production will collapse. He says: when state is filled with oppression and persecution, people cannot merchandize their goods, and eventually their whole efforts confront heavy losses leaving them utterly stagnant. The people may flee the state persecution, and in the quest for bread and butter, try to take asylum somewhere else (Ibn Khaldun, 2001, p: 354). In the course of outlining the dangerous sequence of oppression, Ibn Khaldun narrated a satiric dialogue taking place between a male and 
female owls explained by a pious wise man before Bahram. ${ }^{14}$ Due to spatial limitations, we are mentioning only the dialogue. "Male owl desired to marry the female owl. So he betrothed her. In response to the betrothal, she said: "I will accept your betrothal, if you ruin twenty cities during the tenure of Bahram." He took the challenge, and said to her: "look! If the rule of Bahram continues, I will ruin thousands of cities for you and still my challange would too easy compared to the ruining of so many cities (Ibn Khaldun, 2001, p: 354)."

Then he mentions different aspects of zulm (injustice). For Ibn Khaldun, zulm should not be defined as only taking away property of others or of kingdom without due compensation. It is far greater. To him, any obligation given to any individual which is not obligated by the Law of Sharia, or the collection of any property by the collectors of income departments, from individuals without due course, denying one's rights and misappropriating the offices of public affairs...for sure, amount to biggest oppression (Ibn Khaldun, 2001, p: 354). In sum, to misplace anything or action intentionally is zulm/injustice. For ibn Khaldun, zulm is the worst evil force which alone can destroy the entire civilization.

To substantiate his position on the wider swath of zulm, he imports the higher objectives of Islamic Legislation. He clearly reclaims the role of the five folded higher objectives of Islamic Legislation, i.e., protection of din, of soul, of lineage, of intellect and of property in ensuring justice. So the protection of human civilization, he says, is the central to the five higher objectives of Sharia (Ibn Khaldun, 2001, p: 356-58). No doubt injustice intervenes the noble drives of maqāșid al-Sharī ah. Zulm is pronouncer of pervasive destruction of civilization, the destroyer of human lineage on earth. It should be understood, he argues, that this is the underlying reason why Sharia strictly prohibits zulm. Hence any policy or law facilitates zulm, should be strictly prohibited (Ibn Khaldun, 2001, p: 356).

\subsubsection{Lessons to be Learnt from Khaldunian Jibāyah Tradition}

After having an extensive enquiry into his jibāyah conception in conjunction with the drives of kasb-ma'āsh drive, the following economico-legal model would be worth deriving:

\footnotetext{
14 Perhaps this Bahram was Bahram b. Bahram (276-293), the fifth Sasanid king of Persia. he is reported in Tarīkh al-Rusul wa al-Mulūk by Ibn Jarīr al- Ṭabarī, V.2, P. 54, to have encircled by great scholars and saints of his time and listened to them.
} 
First, as the production industry 15 is the heart of the state economy, the state must keep the interests of the production industry with special focus on agriculture and business sections at the forefront of the fundamental principles of state policies. And therefore, state should introduce a distinct legal and regulatory body who would monitor and protect the industry from going stagnant, and by constantly mapping the changing mechanisms of international economic market, keep adopting policies which help emulate the international economic counterparts. The body as recommended above, shall also advice the state whether to sign any certain intranational treaties that in the long run may undermine the domestic economic policies. According to the Khaldunian treatment of economy in the context of maqāșid al-Shari ah, the state should introduce laws that mandate the leaders of concerned industries to both allocate the well-justified wages for the employees and teach the work forces of all levels about the likely consequences of products and goods' being corrupted and or adulterated which may cost the sustainable goals.

Secondly khaldunian restatement of maqāșid al-Sharitah in his economic discourse impels a host of policy concerns which a given state must reflect in its domestic and international economic activities. For instance, any policy adopted and or law promulgated by the state which instead of reflecting 'adl (justice), facilitates injustice should be declared invalid. Misappropriation of any offices by the concerned officers would be a case in point. Given that the state must undertake two-tiered mechanisms: a. it must ensure an internationally accredited educational climate inspired by the impulse of higher objectives of Humanized legislation which schools and incubates teams of noble human souls who would administer the state machineries beyond any corruption or misappropriation of their offices; $b$. it must empower the state machineries enough enabling the executives to dominantly rule the corporate house of the state.

Thirdly Khaldunian treatment of 'adl-zulm/justice-injustice ${ }^{16}$ binary tells that the state, being the biggest market [compared to the set of domestic markets] on the global scale (Ibn Khaldun, 2001, p: 353), must formulate regional alliances to realize their respective economic interests, and also find out strategic partners who will be of greater help in establishing a common sustainable economic platform.

\footnotetext{
15 As footnoted earlier, this term should not be understood in the narrower sense of existing capitalistic production archetype. Rather it is an idea that covers every single citizen of the state ranging from farmer to a professor of a university as explained in the Khaldunian economic discourse

16 Tellingly injustice implies to the misplacing of anything or being, and justice means to place anything or being where it belongs to. Arguably all four layers of justice-commutative, contributive, distributive and legal justice-are subsumed by the Khaldunian justice-injustice binary.
} 
Fourthly, with the help of regional and strategic partners, the state must determine its list of priorities which would function as a milestone towards attaining the sustainable goals. Last but not least, khakdunian location of jibāyah concerns and policies in the topography of maqāșid al-Shart ah permits us to rediscover the integrated maqāṣidsyiāsa understanding-a nearly forgotten art of Islamic Jurisprudence-which would help address and legist policies ontologically.

As earlier read, one of the core concerns of the present work is how khaldunian iqtișādi tradition may function as an alternative economic model to the orthodoxy western economics. Hence in order to set the premise for the focus on the above claim, the immediate discussion investigates the reasons which are principally responsible for the planet to have been too despicably unsustainable.

\section{An Inquiry into the Reasons of Imbalance Economy}

Smithian paradoxical economic understanding, ES Reinert argues, would merit the founding reason for the planet being so imbalance, because Smithian tradition advises free trade theory while emphasizing that only nations with a native manufacturing industry could ever win a war (Reinert, 2007, p: 25). Perhaps this doctrine later on permitted both the rich countries and international institutions like International Monetary Fund (IMF) to take over the management of the economic affairs of most poor countries. Dani Rodrik views for last few decades the force of globalization has been seriously prohibiting the dormant domestic economy of the nations from accordingly flourishing. ${ }^{17}$ Another author argues that for a nation being poor lies in state machineries not being mutually affiliated with the economic institutions. Extractive economic and political institutions are always at the root of the nation's failure (Acemoglu \& James Robinson, 2012, p: 295). Ricardian comparative advancement theory is also seen to have contributed to the formation of ever-growing discrepancy between the poor and rich.

We argue, though not completely, the reverse that these are obviously some valid reasons but not the pivotal ones, rather some offshoots therefrom. A more thoroughgoing investigation suggests that the pivotal reason rests in the niche of absolutism. The planate has been witnessing the economic players' sheer selfishness and altogether ignoring of the concerns for sustainability in economic affairs,

\footnotetext{
17 "The Globalization Paradox: Democracy and the Future of the World" and "Has Globalization Gone Too Far" by Dani Rodrik, a professor of political economy at Harvard University would offer a handsome grasp on the rapid domino effect of globalization.
} 
governance, society and environment. Such absolutism characterized by huge economic empowerment without any restraint what so ever has forced the poor (individuals and states) to perennially lag behind while allowing the rich (individuals and states) to get richer. And the list goes a long way. With that concern in mind, the following lines will try to find out the underlying reasons which would be responsible for the absolutism to have long been at work.

In our venture to unfold the exact venue of absolutism, we may appreciate the notion of Thorstein Veblen. He thinks that economists' instincts have been contaminated by their education (Reinert, 2007, p: 26) which would be leading them to be paradoxically maintaining two opposite thoughts of rhetoric and reality.

History tells us that economic matters have been taught and discussed as a branch of moral, theological, jurisprudential and political studies. In the mid thirteenth century when Aristotle was resurrected in western Europe, Nichomechean Ethics was used as one of the leading textbooks. From this point forward economics emerged and flourished. Arguably Scholastic economics was none but a by-product of Aristotelian Ethics (Langholm, 1979). Arguably, Scholastic's economics was an intertwined discipline of ethics and theology (Gordon, 1975). For instance, the disputes around the validity of interest were of moral concerns (Hamouda O.F \& Price B. B., 1997, The Justice of the Just Price, The European Journal of the History of Economic Thought 42, 2, 191-216).

This intertwining fashion had continued to exist in the European academia till the mid $18^{\text {th }}$ century so far (Canterbury, 1995). A Short Introduction to Moral Philosophy by Francis Hutcheon, the teacher of Adam Smith would be a case in point whose one of the two parts was law of nature. The latter had involved three sections: private rights, economics and politics (Ross, 1995). Economics is found to have taught within the province of jurisprudence which by definition worked out within the purview of moral philosophy. However during the periods of the $17^{\text {th }}$ and $18^{\text {th }}$ centuries, the dormant resistant for divorcing religion from social life had begun to economically appear through the mercantile pragmatism.

No doubt, being influenced by his teacher Hutcheon, Smith ${ }^{18}$ was also proponent of keeping morality at the core of economics. Smith's student John Miller reasserted the

\footnotetext{
18 Adam Smith though first got appointed as a professor of logic at the university of Glasgow, but later on, shortly after Thomas Craigi, the then professor of Moral Philosophy at the University of Glasgow died in November 1751, he was translated from his Chair of Logic to the now vacant Chair of moral Philosophy. (collected from Introduction, Adam Smith, Lectures on Jurisprudence 1982, 1978)
} 
Smith's stand on moral philosophy. Smith locates economics what he himself taught as political economy under the wider swath of moral philosophic projects. In the Smithian economic scholarship, Virtue and justice occupy a significant place. Smithian economic understanding was thus also closely tied to the morality and ethics. Thomas Malthus, the first professor of political economy is seen to have followed the same track as Smith did. It is worth pointing that nonetheless having strong moral conviction, moral Smith had to finally submit to the liberal Smith in the practices of his brainchildren in the subsequent times. David Ricardo ${ }^{19}$ would be a good example who treats economics as a mere technical subject. One finds him to say how to become rich, but not to advice when to prefer riches to indolence or vice versa (Ricardo, 1821).

Perhaps Ricardian approach to political economy clearly marked the break with the timeold tradition of the existence of morality in economics. Ricardo's Principles of Political economy and Taxation gained him a huge dominance in the discipline leading him to be the extraordinary economist in both academia and public squire. Almost all the economists came after him including some of his contemporaries got influenced by his posivistic economic abstraction. Over the decades Ricardian approach led the economists and natural scientists to restructure the discipline in line with mathematics and physical sciences. Eventually it turned out to be economics, and hence, was left value free.

William Stanley Jevon is the transiting figure for political economy to pass from its earlier form to the stage of modern economics. He was utterly radical in taking the positivistic notion toward economics. He was perhaps the first to see the extended analogy between economic science and physical sciences. His 'Theory of Political Economy' is a testimony to his mechanical and mathematical approach to economics (Schabas, 1990, P.138). Marshall is the immediate next figure who treated the discipline more radically than Jevon's. He was a strong proponent of divorcing economics from moral economy and naming it economics as an independent science (Alvey. E, \& Staveley, 1996, Vol.8). Kenneth E Boulding, a prominent economist and interdisciplinary philosopher, rightly commented: "economics ...only became a science from the casuistry and moralizing of medieval thought (Boulding. E, 1970, p: 117).

Post-Marshall economics had to undergo a heavy burden of deethicalization. A good number of the mathematician economists coming after Marshall throughout twentieth century onward are seen to have positivized the economics which means to rule out

\footnotetext{
${ }^{19}$ A sincere reader of the Wealth of Nations.
} 
economics of moral science. Among many Robbins (Robbins, 1936) and Friedman (Friedman, 1953) are two promising figures who worked it out the said way. Solo views that "between 1940 and 1990...economics became a self-consciously technical subject (Solow M, 1997, How Did Economics Get that Way and What Way Did It Get? Daedalus $126,1,42)$." For good reason, this technichalization might have gradually led them to enveloped themselves in the grip of greed.

\subsection{Summary of the Enquiry}

Adam smith, As Smithian collective intellectual works suggest, was a heart-core proponent of democracy and individual liberty. Tellingly democracy is the reactionary child of medieval theocracy whose central focus was and still is the absolute freedom of individual rights. Capitalism is no doubt the twin of the unqualified conviction of individual rights. Hence slippage from moral concern to absolutism was inherent in the Smithian economic thought. For practical reason, Smithian economic tradition coupled with the Ricardian view, the two Biblical figures ${ }^{20}$ of modern economics are seen to have ultimately facilitated the subsequent economists to divorce the economic studies from moral concerns.

The gradualities and stages modern economics ${ }^{21}$ had to undergo all the way from medieval Scholastics period down to the present days clearly show that economics divorced altogether from ethics and any metaphysical sanctions gave rise to the transaction laws, domestic and international, which are better characterized by the stimuli of unqualified human rights. This unqualified rightism has led certain entities (individuals, corporate houses and states) to be unqualifiedly empowered with massive wealth accumulation to the complete neglect of others. ${ }^{22}$ Eventually both modern economic theory and the laws national and international concerned with economic affairs are left utterly individualistic to a huge mistake in letting them decide to do with their money and wealth whatever, however and whenever they desire, and leaving them unmonitored with what they have decided. Thus, we are inclined to view that today's shockingly opposite economic images of the planate are the products of the collectively synthesized formula of these hyper-individualistic economic-legal ideas.

\footnotetext{
20 So have been branded by Thomas Gerber, see, David Ricardo: His Personality, His Times and His Principles in R.W. Jones, R. Weder (eds.), 200 Years of Ricardian Trade Theory, Spring International Publishing AG 2017. 21 To have a more perceptive understanding, see, Roger E. Backhouse. New Directions in Economic Methodology, London \& New York: Routledge 1994; Abdulkader Cassim Mahomedy. The Ontological Foundations of Modern Economics: How Do They Compare? SAEF Working Paper No. 2016/01/13.

22 This is a clearest demonstration of how Satan whispers the souls to gradually mislead to the destiny of destruction. See the noble Quran, 24:21.
} 
Contrastively Khaldunian iqtișādi tradition asserts the irreconcilable nexus between economic engagement and religious life of both individual and state, and the location of economic discourse in the context of maqāsid al-Sharîah has indeed perfected a comprehensive economico-legal paradigm which would help both establish a strong domestic economy and put the sustainability into practice nationally and globally, and hence gain the true SDGs. The next section sketches the detailed picture of how Khaldunian economic tradition would better function in the realization of the SDGs.

\section{Significance of Khaldunian Economic Tradition to the Sustainability Drives}

Due to the ever-growing discrepancy between the rich and the poor and the plight condition of the planet, the concept of sustainability has emerged and been gradually gaining the dominant position in the priority list of both the economic leaders and the academics. Sustainability has been so far figured out in four different sections. Economical, institutional/governance, social and environmental. Practically speaking, though the SDGs has already attained the age of maturity, the realization of sustainability still remains fetus, because international policies over the sustainable convictions especially economic and environmental is rhetoric yet. As through an uneven economic development, a certain individuals or groups own the maximum resources and wealth of the globe, the policies and regulations have been left almost abortive. Only the inclusively integrated just economic model would work out the SDGs. This paper, as earlier seen, argues Khaldunian economic tradition, being an alternative economic model, is tremendously rich with dormant forces and stimuli which would readily help realize the convictions of SDGs. The below is a discussion of how and why.

So far, the sustainability conviction is concerned, three different blocs would be at work. Individuals, state and international communities. In order to provide effective mechanisms to the four-tiered sustainability, three parties have to play their respective roles accordingly. As earlier seen, the traditional economic theories and policies have remained almost rhetoric while furthering the gap between the poor and the rich more precipitately

Khaldunian economic tradition would help implement four-tiered sustainability in domestic level effectively. As seen above, for Ibn Khladun, a well-nurtured production industry allowing itself to tremendously flourish triggers the advancement of national economy. However, corruption, he thinks, is a demon which would easily corrode the foundation of national economy. Hence in order to attain Economic and institutional 
sustainability, the state shall undertake comprehensive steps home and abroad ensuring every citizen with the age of majority employment facility, and accordingly monitors their conditions. Consequently, the collective efforts of the bulk citizens would turn out to be a strong production industry whose industries and labors bring the state huge incomes. Based on the Khaldunian justice-injustice binary, those incomes must be utilized to empower the citizenry in a much more consolidated way. This expectation would be possible only when a strong transparent executive body committed to bettering the nation dedicate their labors and intellects and mutually work with private sectors alongside their public offices' responsibilities. Hence a meaningful enforcement of kasb$m^{\prime} \bar{a} s h$ drive together with the jibāyah policy would establish economic and institutional sustainability in any given jurisdiction. ${ }^{23}$

In terms of surviving the international economic challenges and paradoxical global governance, which may prohibit any nation from being capable of emulating them accordingly, Khaldunian economic model would suggest three recommendations. The state must introduce an effective manufacturing sector ${ }^{24}$ which may translate every single possibility of work force into internationally tradable product. ${ }^{25}$ Countries with the seemingly maintaining economic interests must formulate a strong regional and strategic alliance which together would empower them to pressure the big brothers not to impose any policy or decision to the exclusion of their respective economic interests. Thirdly almost all the earnings emergent from the existing monetary system are always being credited to the account of powerful countries leading them to be more irresponsible and absolute. Given that, a strong voice must be raised out for an alternative monetary system to be introduced which may help better work out the SDGs.

Khaldunian integrated maqāṣid-syiāsa understanding would allow the law makers to move away from the ever-contradicting one-eyed laws, huge inequality and social instability are whose direct products, and move back to a functionally accommodative legislation leading them to decide the social issues ontologically. Hence, we argue that

\footnotetext{
23 One may question political institutions are seen to be often responsible for both economic and institutional unsustainability. We are better convinced to contend that once a strong transparent executive organ is at work, all sort of political disturbances would be easily removed from the state machineries.

24 Kindly take note we have explored how Ibn Khaldun articulated merchandizing the goods from cities to cities.

25 Here it is worth mentioning that human capital is by far the most valuable capital ever. We argue that training the populace, preparing them in line with the demand of international workforces and finally export them abroad would fall within the purview of effective manufacturing industry.
} 
a due realization of comprehensive Khaldunian economico legal paradigm would easily adress the social sustainability.

In terms of social and environmental sustainability, khaldunian location of jibāyah system in the context of maqāșid al-Sharî ah would recommend a lot of functionaries which may actuate the sustainable goals. It is to be remembered here that protection is the central to the maqāșid paradigm which involves five venues-religion, life, intellect, lineage and property. ${ }^{26}$ Parenthetically speaking, consumerism is the central to the modern life which led the earth to the cataclysmic devastation. Having observed the likely horrible consequences of environmental degradation, the activists have developed a host of green theories, for instance the social practices theory, ${ }^{27}$ which, they hope, may protect the planet including ourselves. However, because of their foundational backdrops, the theories are often left seriously restrained in their capacity to gain the aim.

Empirically speaking a venture of true humanization would protect us from destruction which may be attained by instilling the sense of religiosity into the heart of human being. So far Khaldunian iqtisādi-legal pattern would be a founding device which may successfully restore the function of ethics in the economics studies in particular and in all other fields of sciences in general, and thereby functions meaningfully as an effective alternative economic model mandating the people of all sects nationally and globally to develop behaviors and take decisions in the best interest of the sustainability.

\section{Conclusion}

The khaldunian historical-legal observation of civilizations' wealth management and their rise and fall is seen to have been somewhat echoed by both German economist Gustav Schmoller's (1838-1917) historical approach to economics and the founder and first Dean of Harvard Business School, Edwin Gay's (1 867-1946) case study methodology

\footnotetext{
${ }^{26}$ As known to almost all that these five-folded-paradigm has been structured by Imam Ghazālī. Some later 'ulamā are seen to have added dignity to the Ghazăli paradigm. Imam Ibn al-Qayyim however offered a quadripolar maqāṣid paradigm. According to him, rahmah, hikmah, mașlaha and 'adl are the pivotal premise of maqāșid al-Sharîah. He appears to say that any action/omission goes against these drives would be regarded as a prohibited act by Sharī ah. See, Ibn Qayyim al-Jawziyyah 'Abū 'Abdullah Muh ammad b. Abī Bakr b. Aiyyūb. I'Iām al-Muwaqqa'în 'an Rabb al-'Ālamīn, Verified by Uzair Shams and Authenticated by Ja'far Hasan Sayyid (Makka al-Mukarramah: Dar 'Alam al-Fawaid,1437), $1^{\text {st }}$ ed., Vol. 3, P. 429.

27 To know more, see "Emily Huddart Kennedy, Maurie J Cohen and Naomi T. Krugman. Putting Sustainability into Practice: Application and advances in Research on Sustainable Consumption, (Cheltenham: Edward Elgar Publishing, 2015).
} 
that claim that it is not the mathematical lens but the historical evidence is of the relevance to the pathway towards economic emancipation (Reinert, 2007, P. 4). Arguably Khaldunian economic tradition has massive data to show that failure to protect the domestic production industry through a comprehensive strong legal mechanism led many nations to dire poverty, British Bengal would be a case in point, while a strong legal and regulatory body catering for the national economy triggered their sociopolitical dominance. USA would be a grim illustration of this conviction. Hence khaldunian economico-legal paradigm, if implanted accordingly, would solve the fundamental economic crises of any given nation.

Though Smithian-Ricardian economy contributed to the advancement of economic understanding in both academia and public squire, like the fall of Berlin Wall, their economic traditions placing consumerism at the core of modern life utterly failed in establishing a sustainable globe. Contrastively having learnt from the ups and downs of civilizations across the human history and experienced by the extraordinarily brilliant Islamic intellectual heritage, Ibn Khaldun has located his economico-legal discourse in the context of maqāșid al-Sharîah where religiosity, protectionism, justice and public $\operatorname{good}^{28}$ inspired by the principles of siyāsa shar 'iyyah always stand firm. We are therefore inclined to conclude that Khaldunian inclusive treatment of economic-legal philosophy in the topography of integrated maqāșid-siyāsa landscape would ensure a multitude of founding mechanisms triggering the civilizational existence yet in line with the best interests of sustainability.

\section{Reference}

Al-Qurā'n al-Karīm.

Acemoglu, Daron \& Robinson, James. (2012). Why Nations Fail: the Origin of Power, Prosperity and Poverty. London: Profile Book Ltd.

Aḥmad b. Ḥanbal, Abū 'Abdullāh. (1419/1998). Musnad. Riyāọ: Bait al-Afkār al-Duwaliyyah.

al-Ṭabarī, Abū Ja'far Muhammad b. Jarīr. (ND). Tarīkh al-Rusul wa al-Mulūk. verified by Muhammad Abū al-Faḍl Ibrāhīm. Egypt: Dār al-Ma‘ārif.

Alvey, James E \& Staveley, Richard. (1996). The Value Assumptions Underlying Marshall's Principles of Economics in Alfred Marshall: Critical Assessment, 8 vols., ed. J. C. Wood. London: Routledge.

\footnotetext{
28 Note should be taken that public good inspired by the principles of siyāsa shar'iyyah, a set of behavioural practices that respect the natural course of ecosystem, is meant to exclude the mechanistically defined public good characterized by the growing demands of acultic practices across the globe which is undergoing a heavy chaotic transition.
} 
Alvey. (1999). A Short History of Economics As a Moral Science. Journal of Markets \& Morality 2(1): 53-73.

Boulding, Kenneth E. (1970). Economics As a Science. New York: McGraw Hill.

Canterbury, E. Ray. (1995). The Literate Economist. New York: Harper Collins.

Friedman, Milton. (1953). Essays in positive Science. Chicago: University of Chicago Press.

Gordon, Barry. (1975). Economic Analysis Before Adam Smith. London: Macmillan Publishing Company.

Hamouda, O.F \& Price, B. B. (1997). The Justice of the Just Price. The European Journal of the History of Economic Thought. 42(2): 191-216.

Hosein, Imran N. (2007). The Gold Dinar and Silver Dirham: Islam and the Future of Money. San Fernando: Masjid Jāmia Publication.

'Izz al-Dīn, 'Abd al-'Azīz b. 'Abd al-Salām. Qawā'id al- 'Ahkām fì lṣlāḥ al- 'Anām. Dimashq: Dār al-Qalam.

Ibn al-Qayyim al-Jawziyyah, Abū 'Abdullāh Muḥammad b. Abī Bakr b. Aiyyūb. (1413AH). 'A $/ a \bar{m}$ al-Muwaqqi'īn 'an Rabb al- 'Ālamīn. Verified by Uzair Shams and Authenticated by J'afar Hasan Sayyid. Makka al-Mukarramah: Dār 'Ālam al-Fawā'id.

Ibn Khaldūn, 'Abd al-Raḥmān. (1431AH). Dīwān al-Mubtadā wa al-Khabar fī Tarīkh al-'Arab wa al-Barbar wa Man 'Āṣarahum min Dhawī al-Sulțān al-Akbar. Beirut: Dār al-Fikr.

Ibn Nujaim Zan al-Dīn b. Ibrāīm al- Ḥanafī. al-Ashbāh wa al-Naz̄ācir. Verified by Muhammad Muțī' al- Hāfiż, retrieved from http//: www.fikr.com.

Imām al-Ḥaramain, 'Abd al-Malik b. 'Abdullāh b. yūsuf Al-Juwainī. (2014). Ghiāth al- 'Umam fi al-Tiāth al-Z̦ulam. Jiddah: Dār al-Minhāj.

Kennedy, Emily Huddart; Cohen, Maurie J \& Krugman, Naomi T. (2015). Putting Sustainability into Practice: Application and Advances in Research on Sustainable Consumption. Cheltenham: Edward Elgar Publishing.

Kreps, David M. (1997). Economics: the current position. Daedalus 126(1): 59-85.

Langholm, Odd. (1979). Price and Value in the Aristotelian Tradition. Berlin: University etsforlaget.

Meek, R L; Raphael, D. D. \& Stein, P.G. (1978). Introduction in Smith, Adam. Lecture on Jurisprudence. Oxford: Oxford University Press.

Mill, John Stuart. (1981-1991). Collected Works of John Stuart Mill. ed. Robson, J.M. Toronto: University of Toronto Press.

Proceedings and Documents of the United Nations Monetary and Financial Conference. Bretton Woods, New Hampshire July 1-22, 1944, (Washington: United States Government Printing Office, 1948).

Reinert, Erik S. (2007). How Rich Countries Got Rich... and Why Poor Countries Stay Poor. New York: Carroll \& Graf Publishers.

Ricardo, David. (1973-1989). The Works and Correspondence of David Ricardo. ed. Moggridge, D.E. \& Johnson, E. London: Macmillan Publishing Company.

Robbins, Lionel. (1936). The Nature and Significance of Economic Science. London: Macmillan Publishing Company.

Roger E. Backhouse. (1994). New Directions in Economic Methodology. London \& New York: Routledge. 
Ross, Ian S. (1995). The Life of Adam Smith. Oxford: Clarendon press.

Schabas, Margaret. (1990). A World Ruled by Number. Princeton: Princeton University press.

Smith, Adam. (1976). An Inquiry into the Nature and Causes of the Wealth of Nations. ed. R. H. Campbell and A.S. Skinner. Indianapolis: Liberty Press.

Smith, Adam. (1976). The Theory of Moral Sentiments. ed. D.D. Raphael and A.L. Macfie. Oxford: Oxford University Press.

Solow, Robert M. (1997). How Did Economics Get that Way and What Way Did It Get? Daedalus 126(1): 39-58.

Winch, Donald. (1996). Riches and Poverty. Cambridge: Cambridge University Press.

Yezer, Anthony; Goldfarb, M Robert S. \& Poppen, Paul J. (1996). Does Studying Economics Discourage Cooperation? Watch What We Do, Not What We Say or How We Play. Journal of Economics Perspectives 10(1): 177-186. 